\title{
Reprogramming Human Melanocytes and Melanoma Cells with Yamanaka Factors
}

\author{
İnsan Melanositlerinin ve Melanoma Hücrelerinin Yamanaka \\ Faktörleri ile Yeniden Programlanması
}

\author{
Research Article
}

\author{
Açelya Yılmazer ${ }^{1,2 *}$ and Hadiseh Taheri ${ }^{1,3}$ \\ 'Ankara University, Biomedical Engineering Department, Engineering Faculty, Gölbaşı, Ankara, Turkey. \\ ${ }^{2}$ Ankara University, Stem Cell Institute, Balgat, Ankara, Turkey. \\ ${ }^{3}$ Biotechnology Institute, Ankara University, Tandogan, Ankara, Turkey.
}

\begin{abstract}
A B S TR ACT
The generation of induced pluripotent stem (iPS) cells from somatic cells showed that cell fate could be manipulated by simply introducing a few transcription factors. The differentiation potential of iPS cells has uncovered a wide range of potential applications, including disease modeling, drug screening and regenerative therapy. In this study, we aimed to induce reprogramming of human melanocytes and melanoma cell lines via Sendai viral vectors encoding Yamanaka factors. Following transfection, pluripotent stem cell colonies have emerged in the melanocyte cultures, as evident by phase-contrast and fluorescence microscopy images. However, only cell clusters which were not positive for pluripotency markers were obtained in the melanoma cell cultures. This proved that there are differences between healthy and cancer cell reprogramming. Basal gene expression of Yamanaka factors, pluripotency markers and tumor-suppressor genes have been identified in order to understand the different responses for cell reprogramming in melanocytes and cancer cell lines. Future studies that will allow efficient reprogramming of cancer cells can improve our knowledge about cancer biology and therapy
\end{abstract}

\section{Key Words}

iPS cells, melanoma, melanocytes, Yamanaka factors, cell reprogramming.

\section{öz}

Somatik hücrelerden uyarılmış pluripotent kök (UPK) hücrelerin üretilmesi, hücre kaderinin sadece birkaç transkripsiyon faktörü kullanılarak değiştirilebileceğini göstermiştir. uPK hücrelerinin farklılaşma potansiyeli sayesinde, rejeneratif terapi dahil olmak üzere hastalık modelleme ve ilaç tarama gibi çok çeşitli potansiyel uygulamaları ortaya çıkmıştır. Bu çalışmada, Yamanaka faktörlerini kodlayan Sendai viral vektörleri kullanılarak insan melanositleri ve melanoma hücre dizilerinin yeniden programlanmasını amaçladık. Viral transfeksiyon sonrasında faz kontrast ve flüoresans mikroskobu görüntülemeleri ile melanosit kültürlerinde pluripotent kök hücre kolonilerinin ortaya çıktığı gözlenmiştir. Buna karşın, melanoma hücre kültürlerinde sadece hücre kümelenmeleri oluşmuş ve bunların pluripotens belirteçleri için pozitif olmadıkları belirlenmiştir. $\mathrm{Bu}$ da sağlıklı ve kanserli hücrelerin yeniden programlanması sırasında farklılıklar olduğunu göstermiştir. Yamanaka faktörlerinin, pluripotens belirteçleri ve tümör baskılayıcı genlerin bazal ifade seviyeleri analiz edilerek melanositlerde ve kanser hücre dizilerinde yeniden programlamanın farklı yanıtları anlaşılmaya çalışılmıştır. Kanserli hücrelerin etkin bir şekilde yeniden programlanmasına izin verecek çalışmaların yapılması, kanser biyolojisi ve tedavisi hakkındaki bilgimizi arttıracaktır.

\section{Anahtar Kelimeler}

uPK hücreleri, melanoma, melanositler, Yamanaka faktörleri, hücre programlama.

Article History: Received: May 3, 2017; Revised: Oct 12, 2017; Accepted: Oct 12, 2017; Available Online: Feb 20, 2018.

Dol: 10.15671/HJBC.2018.211

Correspondence to: A. Yılmazer; Ankara University, Biomedical Eng. Dept, Engineering Faculty, Gölbaşı, Ankara, Turkey. 


\section{INTRODUCTION}

ellular reprogramming technologies provide many promising options for the treatment of various diseases, as well as improve our understanding of the biology of these diseases. Upon their discovery in 2006, induced pluriptent stem (iPS) cells have been explored extensively with regenerative medicine purposes and accelerated the fate of cellular therapies. The generation of induced pluripotent stem (iPS) cells from somatic cells showed that the cell fate could be manipulated by simply introducing a few key transcription factors [1]. This conceptual revolution has inspired researchers to reprogram and transdifferentiate a variety of cells in vitro and in vivo for regenerative medicine purposes. The differentiation potential of iPS cells, considered practically equivalent to that of embryonic stem cells, along with the possibility to obtain them from specific human patients has uncovered a wide range of potential applications, including disease modeling, drug screening and regenerative therapy [2-4].

Epigenetic mechanisms, which include DNA methylation, histone modifications and chromatin remodeling, play a major role both in the generation of iPS cells and cancer development [5]. Studies indicate that various epigenetic alterations may happen in pre-malignant cells, leading to their expansion in the early stages of tumor progression and at later stages, more genes might suffer loss of function through epigenetic modification than through genetic defects [5-8]. On the other side, the ability of developmental progression from pluripotent stem cells through progenitors to terminally differentiated cells is accompanied by a gradual deposition of repressive histone marks, followed by chromatin compaction [9-11]. Upon delivery of reprogramming factors to somatic cells, transcription factors bind their recognition elements that are modulated by changes in chromatin structure $[12,13]$. Cancer cells can also acquire pluripotent character by activating some of their transcription factors and modifying some other chromatin regulators. This means that cancer cells can be reprogrammed to pluripotent stage by the expression of Oct3/4, KIf-4, Sox-2, c-Myc transcription factors. This may lead to the erasure of their epigenetic memory and result in modified tumorigenicity.
In this study, we aimed to investigate the reprogramming efficiency of human melanocytes and two different melanoma cell lines. Sendai viral vectors encoding Yamanaka factors (Oct3/4, KIf4, Sox-2 and c-Myc) have been used to generate iPSCs. This is a proof-of-concept study investigating the ability to reprogram melanoma cells into a pluripotent stage and comparing the resulting cells to iPS cells obtained from human melanocytes.

\section{MATERIALS and METHODS}

\section{Cell Culture}

Human melanocytes were obtained from Lonza, and cultured in $\mathrm{MGM}^{\mathrm{TM}}-4$ Melanocyte Growth Medium-4 (Lonza). Human melanoma cell lines A375 and WM115 were purchased from ATCC (USA). Melanoma cells were maintained in Dulbecco's Modified Eagle Medium (DMEM) supplemented with $10 \%$ fetal bovine serum (FBS), $50 \mathrm{U} / \mathrm{ml}$ penicillin, $50 \mu \mathrm{g} / \mathrm{ml}$ streptomycin, $1 \%$ L-glutamine and $1 \%$ non-essential amino acids at $37^{\circ} \mathrm{C}$ in $5 \%$ $\mathrm{CO}_{2}$.

\section{Reprogramming Protocol}

Cells were cultured in 6-well plates in their native culturing medium. Cytotune Reprogramming Kit 2.0 (Life Technologies) was used to generate iPSCs. When the cells reached to 50\% confluency, cells were transfected with Sendai viral vectors encoding Oct3/4, KIf-4, Sox-2 and c-Myc (MOI $5,5,3)$. According to the kit protocol, cells were transferred to inactivated mouse embryonic fibroblast (iMEF, Life Technologies) and cultured in KO DMEM media supplemented with KO serum replacement (20\%), non-essential amino acids (1\%), 2-mercaptoethanol (0.1\%) and b-FGF (4 $\mathrm{ng} / \mathrm{ml}$ ). Cells were observed under an inverted microscope every day in order to observe the formation of pluripotent colonies.

\section{Immunofluorescence Staining}

Cells or colonies cultured on 24-well plates were fixed with cold methanol and blocked with $1 \%$ BSA in PBS. Following blocking, cells were incubated with anti-human Nanog (Abcam) and anti -human TRA-1-60 antibodies for 2 hour at room temperature. Finally, cells were treated with AF488 and AF546 labelled anti- human secondary antibodies. DAPI was used to counterstain nuclei. Repre- 
sentative images were obtained under the EVOS fluorescence microscope (Life Technologies).

\section{RNA Extraction and Quantitative Real Time PCR (qRT-PCR)}

Cells ( $5 \times 10^{5}$ cells) were collected and RNA was extracted with the Machery Nagel RNA isolation kit. cDNA synthesis from $1 \mu \mathrm{g}$ of RNA sample was performed with iscript cDNA synthesis kit (BioRad) according to manufacturer's instructions. $2 \mu$ of each cDNA sample were used to perform real-time RT-qPCR reactions with iO SYBR Green Supermix (Bio-Rad, UK). Samples were run on CFX-96 Real Time System (Bio-Rad) with the following protocol: $95^{\circ} \mathrm{C}$ for $3 \mathrm{~min}, 1 \mathrm{cycle} ; 95^{\circ} \mathrm{C}$ for $10 \mathrm{sec}, 60^{\circ} \mathrm{C}$ for $30 \mathrm{sec}$, - repeated for 40 cycles. GAPDH was used as a reference gene and gene expression levels were normalized to untreated control groups.

\section{RESULTS}

Human melanocytes and 2 melanoma cell lines (A375 and WM115) were used in the reprogramming protocol. Cultures were observed and images under an inverted microscope (Figure 1). Following Sendai viral transfection, colonies have emerged as early as day 15 in the reprogrammed melanocyte cultures, and they became more distinct and similar in morphology to embryonic stem cells by day 20 . For the melanoma cell lines, small cell clusters were observed by day 15 and they did not grow bigger as pluripotent colonies by day 20 . Furthermore, in reprogrammed melanoma cultures, cancer cells proliferated too fast and populated the whole culture dish by the end of day 20 . These results suggested that Sendai viral transfection was able to generate typical iPS cell colonies in the human melanocytes, whereas only cell clusters were formed in the melanoma cell cultures.

Reprogrammed cell cultures were further analyzed for the expression of pluripotency markers (Nanog and TRA-1-60) via immunofluorescence staining (Figure 2). Reprogrammed melanocytes showed Nanog and TRA-1-60 positive cells within the emerged colonies. On the other hand, there were no signals for the pluripotency markers obtained in the reprogrammed melanoma cultures. Therefore, immunofluorescence staining proved that the colonies obtained in reprogrammed melanocyte cultures were pluripotent. Unlike melanocytes, cell clusters formed after viral transfection in the melanoma cultures were not found to be pluripotent.
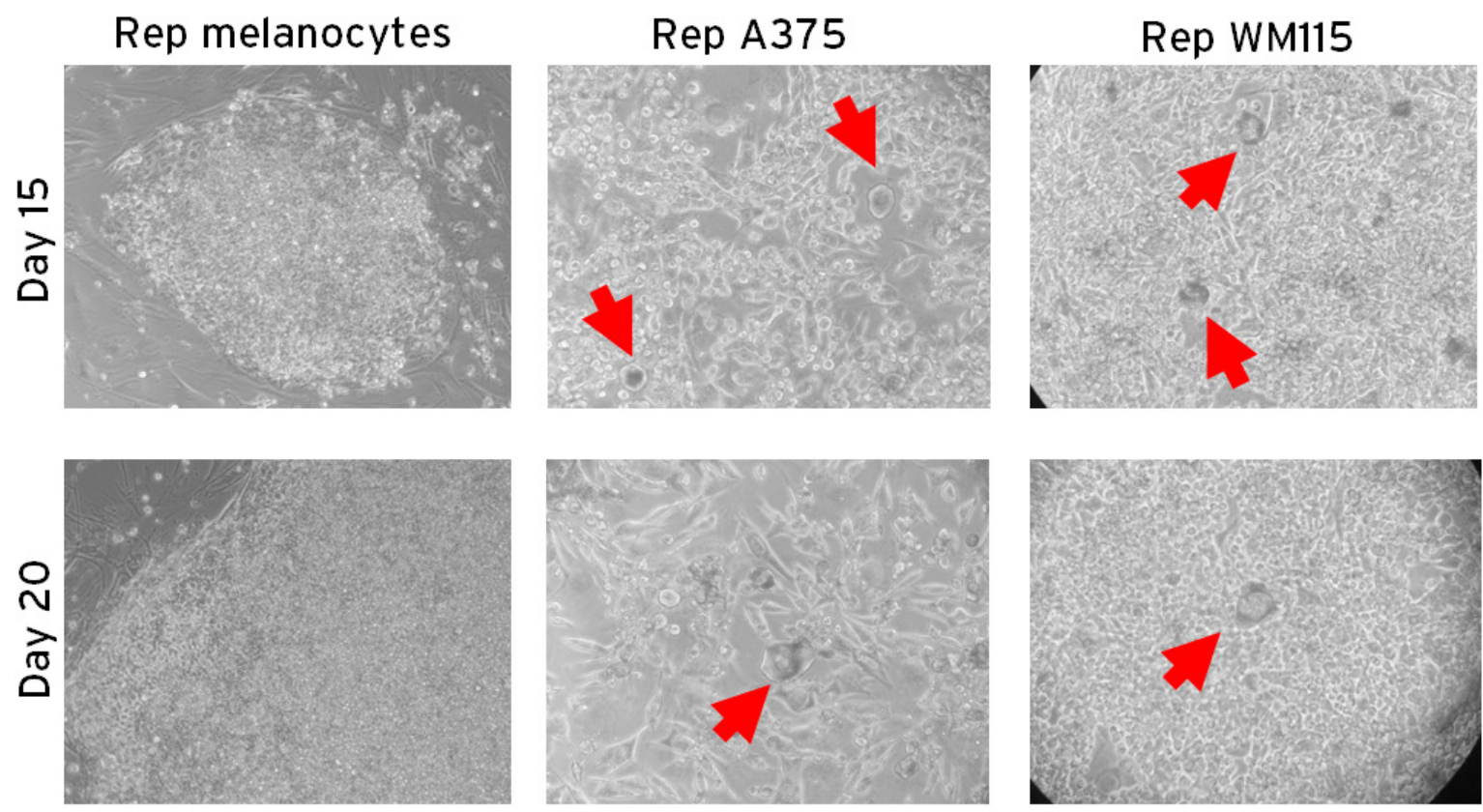

Figure 1. Images of reprogrammed melanocytes and melanoma cells. Human melanocytes and melanoma cell lines (A375 and WM115) were transfected with Sendai viral vectors encoding the Yamanaka Factors. Phase-contrast images (20X) were obtained 15 and 20 days following viral transfection. 

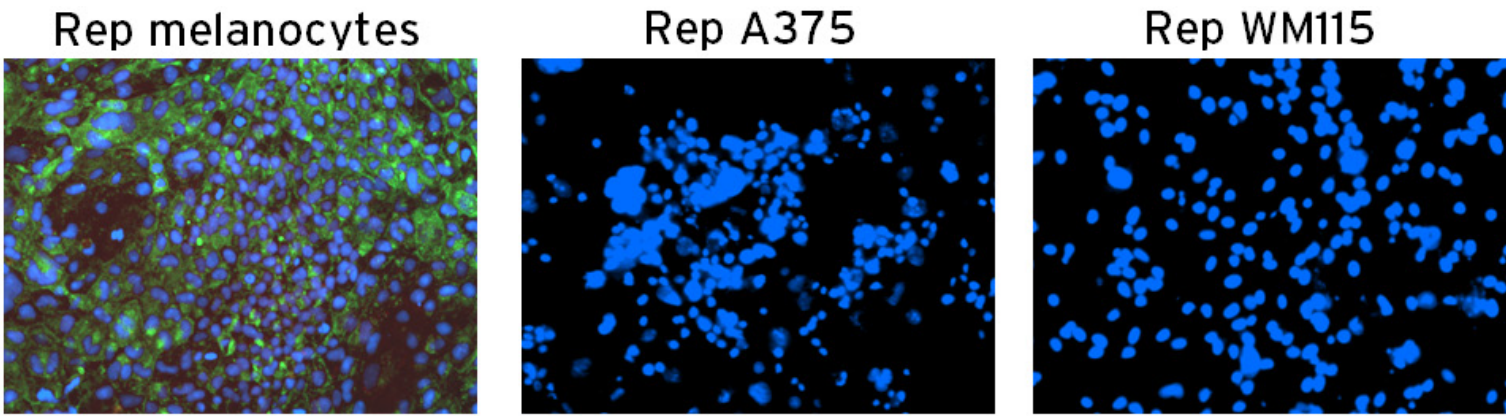

Figure 2. Immunofluorescence staining of reprogrammed melanocytes and melanoma cells. Melanocytes and melanoma cell lines (A375 and WM115) were transfected with Sendai viral vectors encoding the Yamanaka Factors. Cultures were fixed and stained for Nanog (red) and TRA-1-60 (green) expression. Nuclei were counterstained with DAPI (blue). Representative images were obtained using a fluorescence microscope (20X).
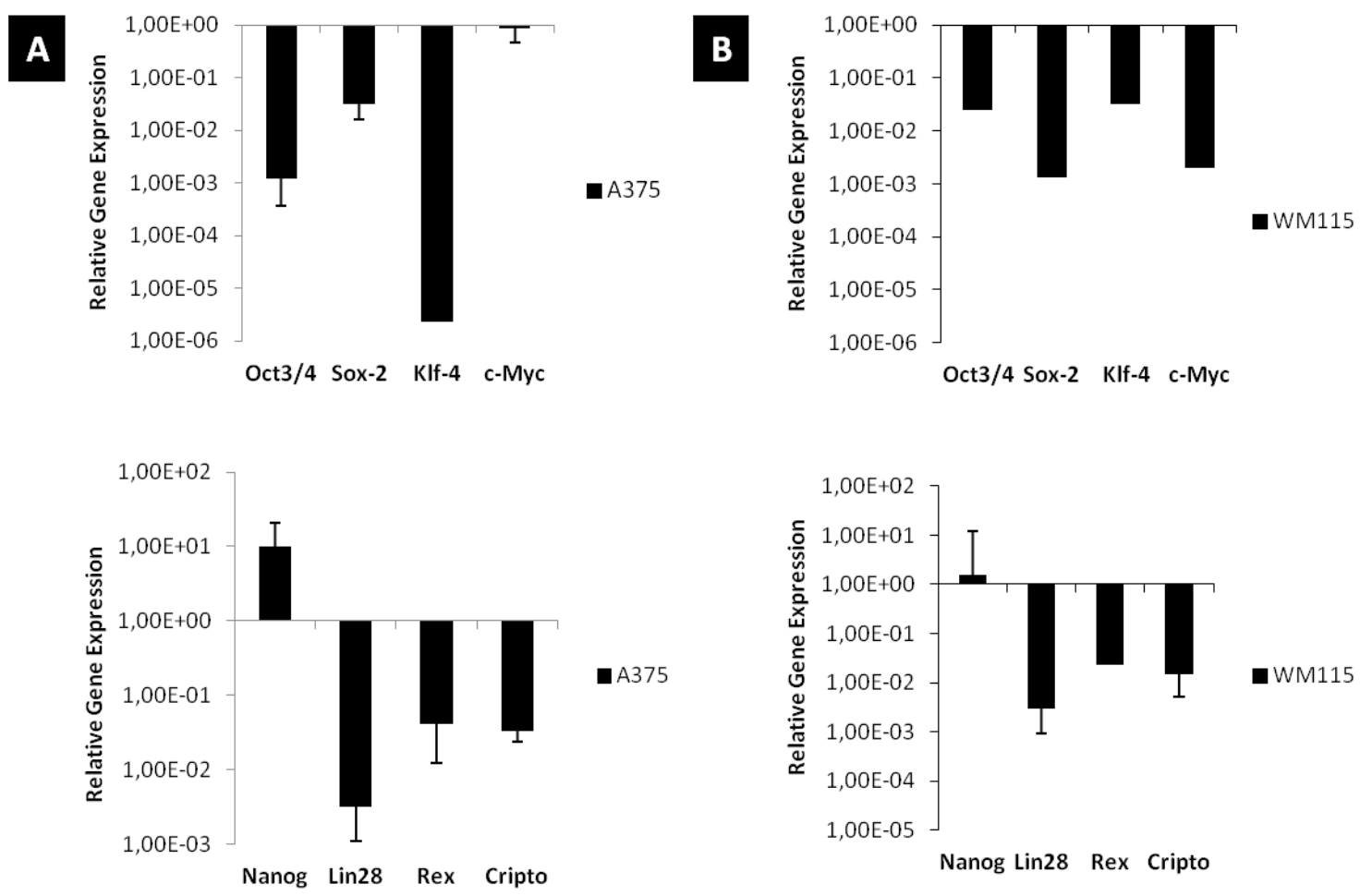

Figure 3. Expression of Yamanaka factors and pluripotency markers in reprogrammed melanocytes and melanoma cells. Melanocytes and melanoma cell lines (A375 and WM115) were transfected with Sendai viral vectors encoding the Yamanaka Factors. RNA was isolated after 21 days and qRT-PCR was performed. Gene expression levels were plotted as relative gene expression (normalized to melanocytes). GAPDH was used as a reference gene.

In order to explore the differences between the reprogrammed melanocytes and melanoma cells, we analyzed the basal expression levels of Yamanaka factors (Oct3/4, Klf-4, Sox-2 and c-Myc) and pluripotency markers (Nanog, Lin28, Rex, Cripto) in naïve cancer cell lines. According to the qRT-PCR data (Figure 3), nearly all Yamanaka factors and pluripotency markers in A375 and
WM115 were downregulated compared to human melanocytes. Only Nanog showed up to 10 times upregulation in melanoma cells.

In literature, it has been reported that expression of tumor suppressor genes can inhibit iPSC generation and reduce reprogramming efficiencies. For that reason, P16, P21 and P53 expression were 

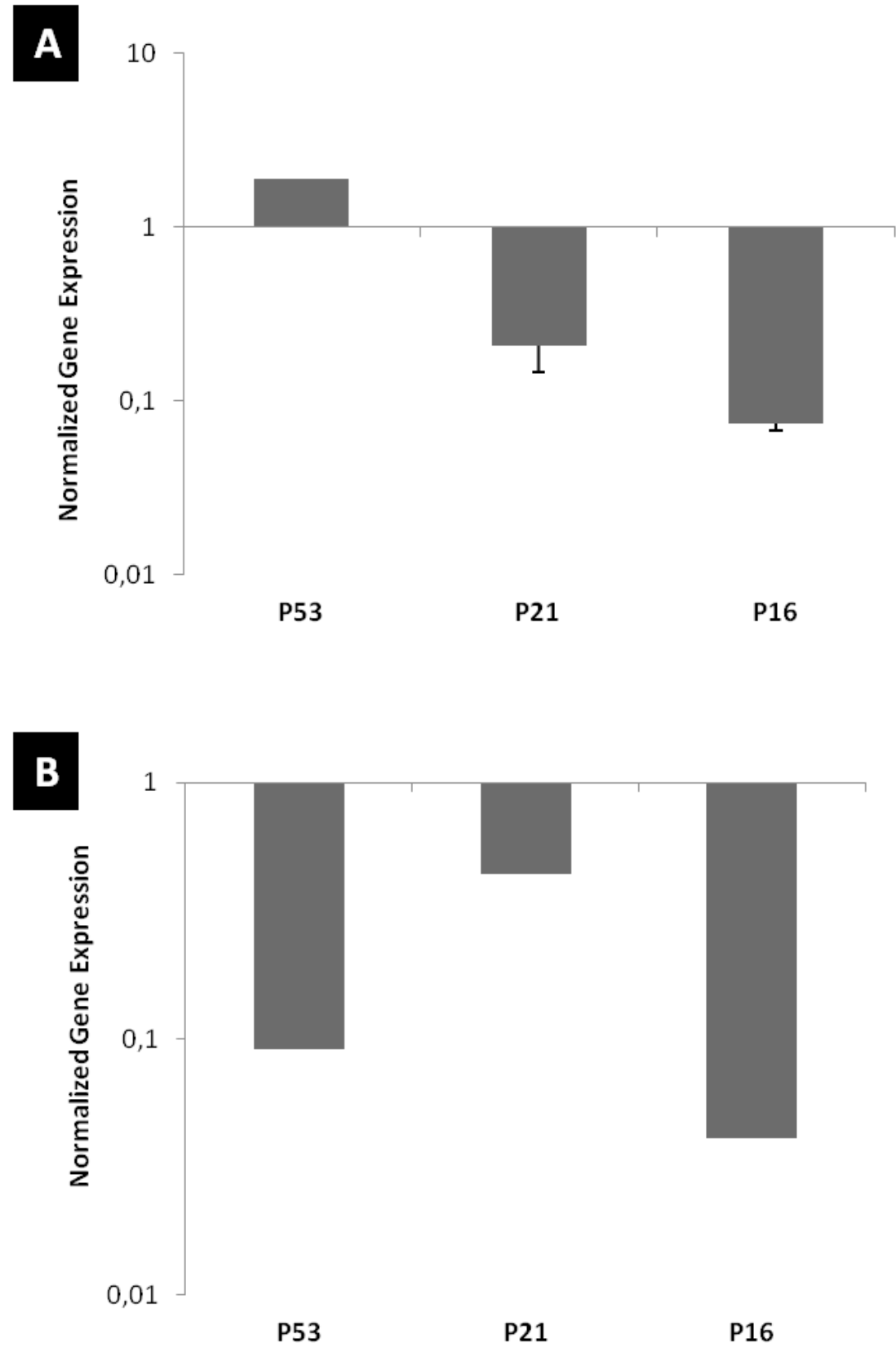

WM-115

Figure 4. Expression of tumor-suppressor genes in reprogrammed melanocytes and melanoma cells. Melanocytes and melanoma cell lines (A375 and WM115) were transfected with Sendai viral vectors encoding the Yamanaka Factors. RNA was isolated after 21 days and qRT-PCR was performed. Gene expression levels were plotted as relative gene expression (normalized to melanocytes). GAPDH was used as a reference gene.

assessed in naïve melanoma cells. According to the Figure 4, when compared to human melanocytes, A375 cells had 2 times higher expression of P53 gene, whereas P16 and P21 showed up to 10 times lower gene expression. In WM115 cells, all of the tumor-suppressor genes showed downregualtion compared to human melanocytes.

\section{DISCUSSION}

In this study, we aimed to induce reprogramming of human melanocytes and melanoma cell lines via Sendai viral vectors encoding Yamanaka factors. Following transfection, pluripotent stem cell colonies have emerged in the melanocyte cultures, as evident by phase-contrast and fluorescence microscopy images. However, only cell clusters which were not positive for pluripotency markers were obtained in the melanoma cell cultures. 
This proved that there are differences between healthy and cancer cell reprogramming. In the reprogrammed melanoma cultures, due to higher cell proliferation rates compared to melanocytes, cancer cells grew faster than the cell clusters, and possibly inhibited the formation of pluripotent colonies.

In order to further examine the different responses of melanocytes and melanoma cells to cellular reprogramming, we analyzed the basal gene expression levels of various factors, including Yamanaka factors, pluripotency markers and tumor suppressor genes. Compared to melanocytes, cancer cells showed lower gene expression levels for most of the Yamanaka factors and pluripotency markers, which could account for the inefficient cellular reprogramming in melanoma cells. When the expression of tumor-suppressor genes were analyzed, cancer cells in general expressed lower levels of P16, P21 and P53, suggesting that they were not the main reason of inefficient cancer cell reprogramming. Not only basal expression levels of reprogramming and pluripotency factors, but also epigenetic basis of cancer, long-term culture conditions, heterogeneity of tumors and presence of cancer stem cells have been reported to be important players of cancer cell reprogramming [14]. Therefore, further studies are needed to delineate the other factors determining the fate of cancer cell reprogramming in melanoma cells.

This study suggests that the rate of cell proliferation, endogenous levels of Yamanaka factors, and pluripotency markers play a key role during cellular reprogramming and iPS cell generation. Future studies that will allow efficient reprogramming of cancer cells can open up new windows for cancer biology and therapy. Tumorigenesis and cellular reprogramming share common biological processes, therefore, transcription-factor based cancer cell reprogramming can provide a powerful tool to improve our knowledge about cancer-fate processes, with a potential to develop novel therapeutic approaches.

\section{ACKNOWLEDGEMENT}

AY and HT acknowledge support by the Scientific and Technological Research Council of Turkey (TUBITAK, grant number 113S897). Authors confirm that there are no known conflicts of interest associated with this publication.

\section{References}

1. K. Takahashi, S. Yamanaka, Induction of pluripotent stem cells from mouse embryonic and adult fibroblast cultures by defined factors, Cell, 126 (2006) 663-76.

2. I.H. Park, N. Arora, H. Huo, N. Maherali, T. Ahfeldt, A. Shimamura, M.W. Lensch, C. Cowan, K. Hochedlinger, G.Q. Daley, Disease-specific induced pluripotent stem cells, Cell, 134 (2008) 877-86.

3. F.T. Merkle, K. Eggan, Modeling human disease with pluripotent stem cells: from genome association to function, Cell. Stem Cell, 12 (2013) 656-68.

4. J. Sng, T. Lufkin, Emerging stem cell therapies: treatment, safety, and biology, Stem Cells Int., 2012 (2012) 521343.

5. M.A. Dawson, T. Kouzarides, Cancer epigenetics: from mechanism to therapy, Cell, 150 (2013) 12-27.

6. S.B. Baylin, J.E. Ohm, Epigenetic gene silencing in cancer - a mechanism for early oncogenic pathway addiction?, Nat. Rev. Cancer, 6 (2006) 107-116.

7. A.P. Feinberg, B. Tycko, The history of cancer epigenetics, Nat. Rev. Cancer, 4 (2004) 143-153.

8. P.A. Jones, S.B. Baylin, The fundamental role of epigenetic events in cancer, Nat. Rev. Genet., 3 (2002) 415-428.

9. C.A. Gifford, Michael J. Ziller, H. Gu, C. Trapnell, J. Donaghey, A. Tsankov, A.K. Shalek, D.R. Kelley, A.A. Shishkin, R. Issner, X. Zhang, M. Coyne, J.L. Fostel, L. Holmes, J. Meldrim, M. Guttman, C. Epstein, H. Park, O. Kohlbacher, J. Rinn, A. Gnirke, E.S. Lander, B.E. Bernstein, A. Meissner, Transcriptional and epigenetic dynamics during specification of human embryonic stem cells, Cell, 153 (2013) 1149-1163.

10. W. Xie, M.D. Schultz, R. Lister, Z. Hou, N. Rajagopal, P. Ray, J. W. Whitaker, S. Tian, R.D. Hawkins, D. Leung, H. Yang, T. Wang, Ah Y. Lee, S.A. Swanson, J. Zhang, Y. Zhu, A. Kim, J.R. Nery, Mark A. Urich, S. Kuan, C.-a. Yen, S. Klugman, P. Yu, K. Suknuntha, N.E. Propson, H. Chen, L.E. Edsall, U. Wagner, Y. Li, Z. Ye, A. Kulkarni, Z. Xuan, W.-Y. Chung, N.C. Chi, J.E. AntosiewiczBourget, I. Slukvin, R. Stewart, M.Q. Zhang, W. Wang, J.A. Thomson, J.R. Ecker, B. Ren, Epigenomic analysis of multilineage differentiation of human embryonic stem cells, Cell, 153 (2013) 1134-1148.

11. J. Zhu, M. Adli, J.Y. Zou, G. Verstappen, M. Coyne, X. Zhang, T. Durham, M. Miri, V. Deshpande, P.L. De Jager, D.A. Bennett, J.A. Houmard, D.M. Muoio, T.T. Onder, R. Camahort, C.A. Cowan, A. Meissner, C.B. Epstein, N. Shoresh B.E. Bernstein, Genome-wide chromatin state transitions associated with developmental and environmental Cues, Cell, 152 (2013) 642-654. 
12. B. Papp, K. Plath, Epigenetics of reprogramming to induced pluripotency, Cell, 152 (2013) 1324-43.

13. R.P. Koche, Z.D. Smith, M. Adli, H. Gu, M. Ku, A. Gnirke, B.E. Bernstein, A. Meissner, Reprogramming factor expression initiates widespread targeted chromatin remodeling, Cell. Stem. Cell, 8 (2013) 96-105.
14. A. Yilmazer, I. de Lázaro, H. Taheri, Reprogramming cancer cells: a novel approach for cancer therapy or a tool for disease-modeling?, Cancer Letters, 369 (2015) 1-8. 
